\title{
離散值系ウェーブレット変換による 電子回路基板中の電流分布解析
}

\author{
学生員 緑川 洋一（法政大） \\ 正員 增田 則夫（日本電気 (株)資源環境技術研究所） \\ 正員 斎藤 兆古 （法政大） \\ 正員 遠矢 弘和 （日本電気 (株) 資源環境技術研究所）
}

\section{Discrete Wavelets Analysis of Current Distributions on the Printed Circuit Boards}

\author{
Yoichi Midorikawa, Student Member (Hosei University) \\ Norio Masuda, Member (Resources and Environment Protection Research Labs., NEC Corporation) \\ Yoshifuru Saito, Member (Hosei University) \\ Hirokazu Tohya, Member (Resources and Environment Protection Research Labs., NEC Corporation)
}

\begin{abstract}
Discrete wavelets transform is widely used for the wave and image analysis. Particularly, multi-resolutional analysis is extremely useful tool for the noise reduction. On the other side, electromagnetic field coming from the printed circuit boards (PCB) is becoming one of the noise sources according to the rising up the operation frequency of central processing unit (CPU). In order to reduce the noise coming from PCB, it is extremely important to grasp the dominant current distributions on the PCB.

In the present paper, we apply the discrete wavelets analysis to the noise reduction of the current vector distributing on the PCB. Numerical and practical examples demonstrate that the noise current vectors are dramatically removed by our approach.
\end{abstract}

キーワード : ウェーブレット解析、ベクトル、電磁ノイズ、プリント基板

Keyword: wavelet transform, vector, electromagnetic fields noise, printed circuit boards

\section{1.まえがき}

近年フーリエ変換を拡張した概念に基づく連続系ウェい ブレット変換が提案され、フーリエ変換では得られなかっ た原空間情報（たとえば時間波形ならば時閒軸情報）が近 似的にも得られることから、波形解析八広範に応用される ようになった 1,2。他方、連続系ウェーブレット変換を雄散 值系で取り扱うことから基底関数が直交守る離散值系ウェ ーブレット変換が導かれ、この離散值系ウェーブレット変 換は単純な線形変換であり、波形や画像のデータの王縮や ノイズ低減に有効であることが知られている ${ }^{3}$ 。

一方、パーソナルコンピュータやワークステーションの
高機能・高速化の必要にともない CPU の動作周波数は高速 化の一途をたどっている。このような CPUの動作周波数増 加によって演算速度の高速化が実現されているが、計算機 周辺へ放射卞る電磁界ノイズの大きさと周波数も増加し、 電磁環境工学的観点から何らかの対策が必要亡なりつつあ る。この闍題を解決する基礎研究として、CPUを搭載した プリント基板から生ずる磁界分布測定から基板上の電流心 クトル分布が推定可能上なりつつある ${ }^{4,5.7 .8}$ 。

本論文は、電流ベタトル分布のようなベクトルデータの 処理に、一般にスカラデータの好理に用いられる離散值系 ウェーブレット変換を抎張し、ベクトルデ一タ内の支配的 なベクトル分布を抽出寸るベクトルデータノイズ処理の1 
方法を提案する。

通常、離散值系ウェーブレット変換は離散化された時間 波形やイメージデータなどのスカラーデータに適用される。 ところで、電流べクトルなどのベクトル量を漏散化して得 られるデータは互いに直交する成分から構成される。この ような離散化されたベクトルデータにスカラーデータの処 理に用いられる離散值系ウェーブレット変換を如何に適用 するかが本論文の課題である。すなわち、雇散值系ウェー ブレット変換をベクトルデータの解析に拡張し、データの 特徽抽出を行うものである。一般に、局所的な磁界分布情 報から需流ベクトル分布を求める問題は逆問題とよばれ不 適切問題を解くこととなり解に誤差を多く含む ${ }^{4.5,7 \sim 11}$ ここの ような逆問題解析手法により求められた具体的な電流ぶク トル分布に離散值系ウェーブレット変換を適用し、CRUを 搭載するプリント基板上の支配的電流ベクトル分布を抽出 する。

\section{2 ベクトルウェーブレット変換}

〈2.1〉基礎方程式 いま、Zが 2 のバき乗個の要素 からなるデータベクトル、Wがウェーブレット変換行列と すれば、離散值系ウェーブレット変換は次式で行われる。。

$$
\mathbf{Z}^{\prime}=W \mathbf{Z}
$$

Z’をウェーブレットスペクトラムと呼5゙ ${ }^{3,6}$ 。逆変換は 変換行列 $W \omega$ 転值行列 $W^{\top}$ を左からZ'人掛け算することで 行われる。

Zが互いに直交するX，Yの2成分からなる 2 次元べク トルを離散化して得られたデー夕、すなわち

$$
\begin{aligned}
& \mathbf{Z}=\mathbf{X}+\mathbf{Y} \\
& \mathbf{Z}=\left[\begin{array}{cccc}
\left(x_{11}, y_{11}\right) & \cdots & \cdots & \left(x_{1 n}, y_{1 n}\right) \\
\vdots & \ddots & & \vdots \\
\vdots & & \ddots & \vdots \\
\left(x_{m 1}, y_{m 1}\right) & \cdots & \cdots & \left(x_{m n}, y_{m n}\right)
\end{array}\right] \\
& \mathbf{X}=\left[\begin{array}{cccc}
\left(x_{11}, 0\right) & \cdots & \cdots & \left(x_{1 n}, 0\right) \\
\vdots & \ddots & & \vdots \\
\vdots & & \ddots & \vdots \\
\left(x_{m 1}, 0\right) & \cdots & \cdots & \left(x_{m n}, 0\right)
\end{array}\right] \\
& \mathbf{Y}=\left[\begin{array}{cccc}
\left(0, y_{11}\right) & \cdots & \cdots & \left(0, y_{1 n}\right) \\
\vdots & \ddots & & \vdots \\
\vdots & & \ddots & \vdots \\
\left(0, y_{m 1}\right) & \cdots & \cdots & \left(0, y_{m n}\right)
\end{array}\right]
\end{aligned}
$$

とする。 $x_{j i}, y_{j i}$ ，位位置 $(\mathrm{i}, \mathrm{j})$ 点にお゙けるそれぞれ $x$ 方向成分、 $y$ 方向成分である。但し、各成分は直交しているから、両者 の内積は $\mathbf{X} ・ \mathbf{Y}=\mathbf{0}$ である。この場合、（1）式の自然な拡張 として、ウェーブレット変換は、

$$
\begin{aligned}
\mathbf{Z}^{\prime} & =W \mathbf{Z} \\
& =W \mathbf{X}+W \mathbf{Y} \\
& =\mathbf{X}^{\prime}+\mathbf{Y}^{\prime}
\end{aligned}
$$

\section{で行われる。}

よって、ベクトルウェーブレット変換はベクトルを構成 する各成分毎に変換することでなされる。

\section{〈2.2〉ノイズ低減}

2.2.1 サンプルデータ ここでは具体的なベタトルデー 夕を取り上げて検討する。ベクトルデータとは、 $x, y$ 平面上 の任意の点に括ける電流の大きさと方向を矢印で表した電 流ベクトルの分布データなどである。図 1 にサンプルデー タを示す。図1で、(a)は真のデータ、(b) は振幅と方向を それぞれ確率分布が正規分布となる乱数により作成したノ イズデータ、さらに(c)は(a) と (b)の和からなるノイズを含 んだデータである。ここでの課題は、このノイズを含んだ データ(c)から如何に(b)のノイズ成分を低減し、(a)図に示 寸真のデータ成分を抽出するかである。

2.2.2データ圧縮法 通常、ウェーブレットスペクトラ 厶 Z' は先頭要素から順に原データ Z の平均的情報から局 所的情報を集約する要素で構成されている ${ }^{3}$ 。従って、平均 的情報 (低次のウェーブレットレベル情報) を残し局所的情 報(高次のウェーブレットレベル情報)を除くことでデータ が压縮される。すなわち、一次元データの波形解析の場合 ${ }^{3,6}$ と同様に高次のウェーブレットレベルの情報をノイズと 見なし除くことでノイズが低減されることとなる。これが データ圧縮によるノイズ除去の原理である。。

図 2 にドビッシーの 2 次基底を用いて図 1 (c) のサンプル データをウェーブレット変換したスペクトラムを示す。図 2(a)，(b)は図 1(c)のサンプルデータの $\mathrm{x}$ 方向成分のみ $\mathrm{y}$ 方 向成分のみ吕らなる $\mathrm{X}, \mathrm{Y}$ 行列をそれぞれウェーブレット変 換した結果である。図2(c)はウェーブレットスペクトラム の大きさを示す。図中の濃度の濃い部分は值が小さく、濃 度が明るい部分ほど值が大きい。従って、X'，Y'何れの スペクトラム成分も原点付近へ值の大きいスペクトラムが 集まっていることが判る。

図 2で、ウェーブレットスペクトラムの大きい值の含ま れる元のデータの $1 / 4 の(1,1)$ から $(8,8)$ の正方領域のみを 残し他の要素を総てゼロとして、逆変換し再現されだ゙タ トル分布を図 3 に示す。図 1 (a)，(b) と比較すれば、図 3 は 明らかにノイズが低減され、図1(a)に類似したベクトル分 布である。よって、ウェーブレットスペクトラムの原点付 近要素のみを残し他の要素を総てゼロとする単純なデータ 圧縮法でノイズベクトルの低減が可能であることがわかる。 また、図 4 にウェーブレットスペクトラムを残寸領域を $(1,1)$ 力ら全領域 $(16,16)$ まで変化させたとき、図 1(a) との 一致度合いを示す相関係数 ${ }^{(3)}$ を示す。ここで、相関倸数はX 成分、Y成分ごとに求め、これらの平均值とした。この結果 より、図 1(c) と図 1(a)のデータ間の相関倸数は 0.691であ るのに対して、図 3 の結果と図 1(a)のデータ間の相関係数 は 0.841 となる。また、図 4 より残す領域を元の領域の $(16,16)$ から $(8,8)$ の $1 / 4$ 領域とした場合が相関係数が最大 となっている。 


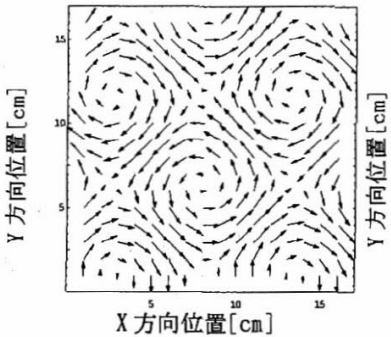

(a) 真のベクトルデータ

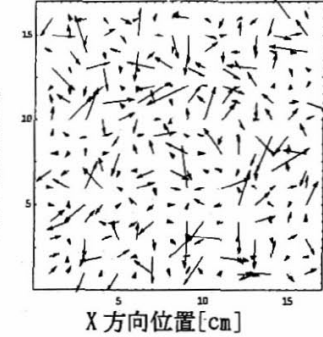

(b) ノイズベクトル

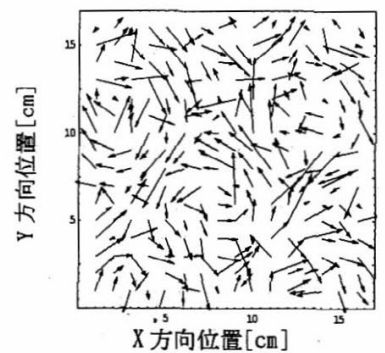

(c)ノイズを含んだベクトルデータ

図 1 サンプルデータ

Fig.1 Sample data.

(a) Exact vector data, (b)Noise data and (c)Noisy data.

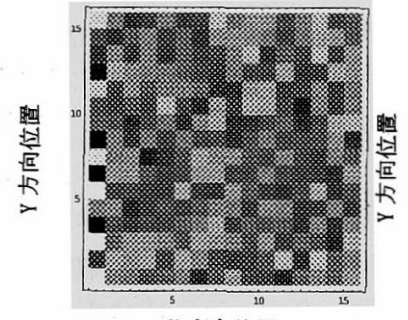

X方向位置

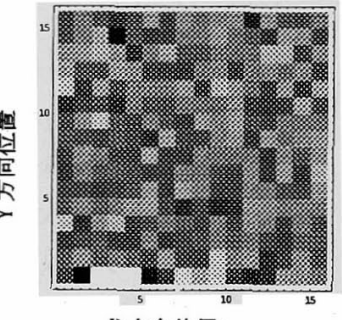

$x$ 方向位置

(a) X 成分スペクトラム

(b)Y 成分スペクトラム

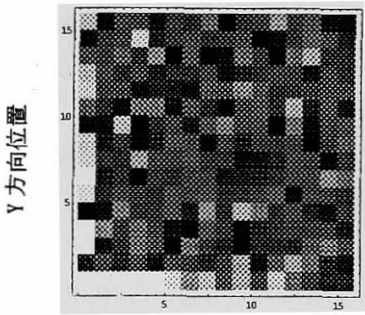

$\mathrm{X}$ 方向位置

(c) スペクトラムの大きさ

図 2. ドビッシーの 2 次基底によるサンプルデー 夕図 1 (c) の X, Y 成分スペクトラム

Fig2 $\mathrm{X}, \mathrm{Y}$ wavelet spectrum components of sample data (fig.1(c)). (a) $\mathrm{X}$-spectrum, (b) $Y$-spectrum, (c)spectrum magnitude.

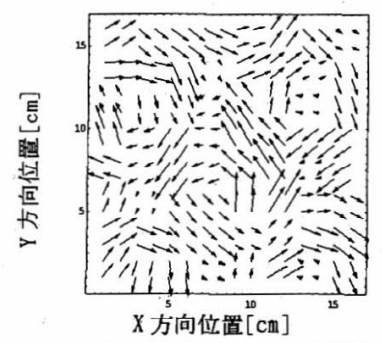

図 $3.16 \times 16$ のデータを $8 \times 8$ へ圧縮したスペクト ラムから再現されたベクトル分布

Fig.3 Recovered vector distribution

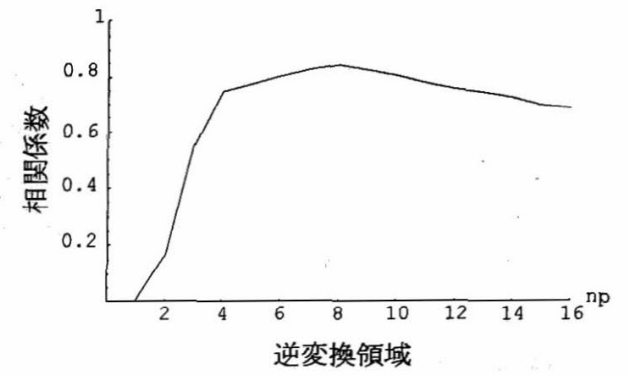

図 4. 相関係数 (データ圧縮法)

Fig.4. Correlátion coefficient. (The data compressed method.)

2.2 .3 多重解像度解析法 データの多重解像度解析とは ウェーブレットスペクトラムを一括して逆変換せず、各ス ペクトラムの持つ情報を抽出する解析である。これは、ウ ェー゙ブレットスペクトラムの組を個々にウェーブレット逆 変換することで行われる ${ }^{3}$ 。

図 4 にドビッシーの 2 次基底によるサンプルデータ図 1 (c)の多重解像度解析結果を示す。解像度レベルは 5 段階で あり、ウェーブレットレベル $1,2,3,4,5$ はそれぞれ全体を

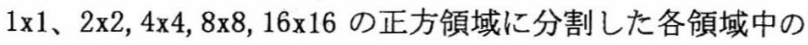
ベクトルを示している。

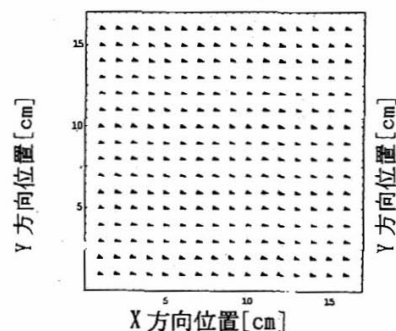

(a) Wavelet Level 1

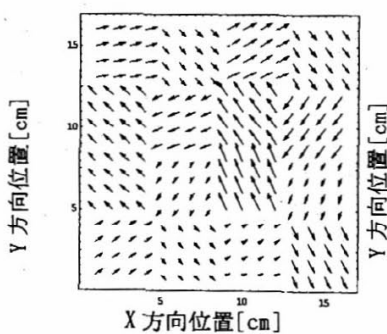

(c) Wavelet Level 3

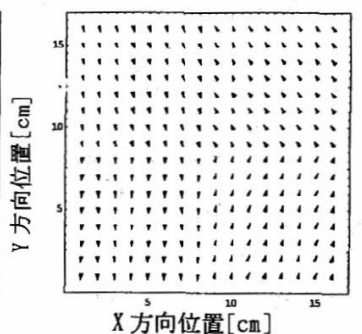

(b) Wavelet Leve1 2

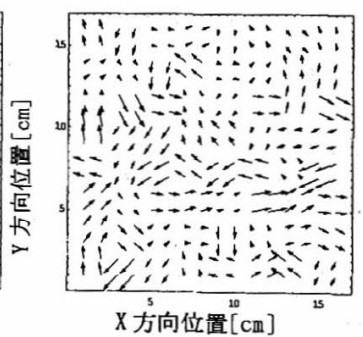

(d) Wavelet Level 4

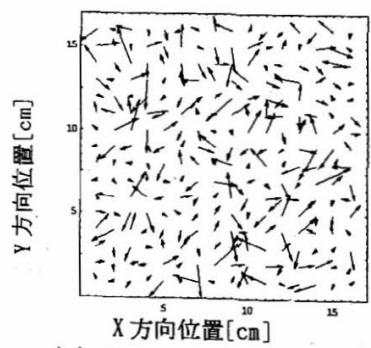

(e) Wavelet Level 5

図 5. ドビッシーの 2 次基底によるサンプルデータ の図 1(c)の多重解像度解析結果

Fig.5 Multi dimensional analysis of sample data.

明らかに、ウェーブレットレベル 5 のベクトルはランダ ムな方向を持つノイズベクトル分布である。図 5(e)のウェ 
ーブレットレベル5 のベクトルと図 1(a)のベクトルデータ との相関係数は 0.0922 となり小さい。図 1 (c)のサンプル データからこのノイズベクトル分布を除いた結果を図 6 に 示す。

図6の結果と図 1 (a)，(c)を比較すれば、図 1(c)加らノイ ズベクトルが低減されていることが判る。また、ウェーブ レットレベル 1 から各レベルまでの総和と図 1(a) との相関 係数を図 7 に示す。この結果、図 1(c)と図1(a)の相関係数 が 0.691 であるのに対し図 6 の結果は相関係数 0.841 とな る。多重解像度解析法によるノイズベクトルの低減法は、 除かれるノイズベクトル分布が予め抽出できる特徽を持つ。

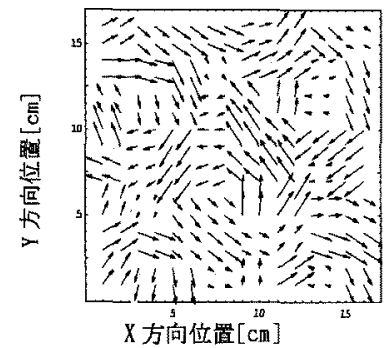

図 6.ウェーブレットレベル1から40和から再 現されたベクトル分布

Fig.6 Vector by the summation of wavelet level components $(1 \sim 4)$.

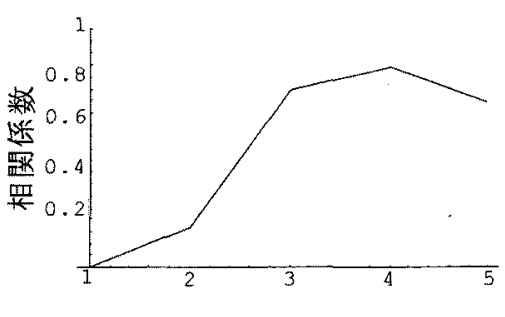

図 7. 相関係数 (多重解像度解析法)

Fig.7. Correlátion coeffìcient. (Multi dimensional analysis)

\section{〈2.3〉ループアンテナの電流分布}

2.3.1 案験による電流ベクトル分布 図 8(a)に测定対象 としたループアンテナを示す。この2つのループアンテナ に同一周波数の電流を流す。電流は図 8 (b)のように流れる。 推定面直上の法線方向成分磁界 $\mathrm{Hz}$ の分布をサーチコイルに より測定し、逆問題解析法の一手法である直接逆行列法を 用いて推定した電流べタトル分布を図 9 に示す 781011 。実験 は $20 \mathrm{MHz}, 40 \mathrm{MHz}, 80 \mathrm{MHz}$ の各周波数について同様の方法でそ れぞれ行った。一般に、逆問題解析法による推定結果は览 密解を与えず、周辺に分散したした形の分布で求まる。図 9 からループアンテナ周辺に大きな電流ベクトルが存在して いることがわかる。しかし測定時のノイズや局所的な磁界 分布情報から電流ベクトル分布を求める逆問題解析法によ る推定であるため誤差などがあり、ループアンテナ以外の ところにも電流ぶクトルが存在し 2 つのループ電流を明確 に区別できない 4, 5, 7,8,9,10,11。

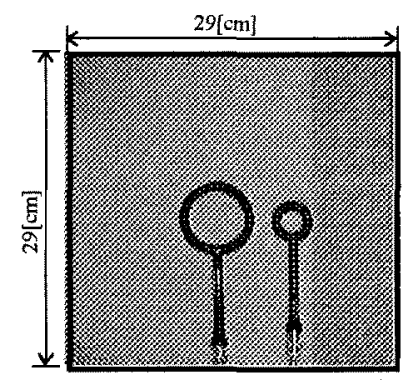

(a) The loop antennas

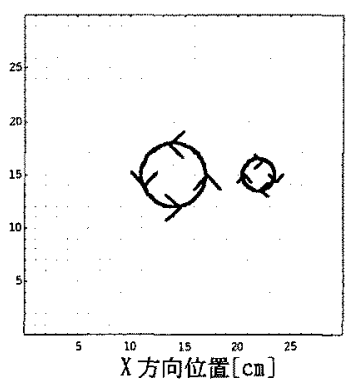

(b) Exact current
図 8. 測定対象のループアンテナ

Fig. 8 Measurement area on the loop antennas.

2.3.2 電流ベクトル分布ノイズ処理 図 10 にデータ圧縮 法によって図 9 の電流ベクトル分布からノイズベクトルを 低減した結果を示寸。ウェーブレット变換を行うためにデ 一夕数を 2 のべき乗とする必要がある 3 。このため 1 成分当 たりの $29 \times 29$ 個のデータに0 要素を追加し、1ベクトル成 分当たり $32 \times 32$ 個のデータとした ${ }^{9}$ 。1 ベクトル成分当た り $32 \times 32$ 個のスペクトラムを $16 \times 16$ 個八王緶した。また、 採用した基底関数はドビッシーの8 8 次である 1,2,3,5,6。図 10 の結果性、明らかに図 9 中のループアンテナに流れる電流 分布を抽出している。な押、図 9〜12 に図 8(b)に示寸電流 経路を重ねて示した。

次に多重解像度解析を行いノイズを低減した結果を図 11 に示す。図 11 の結果は、図 10 の結果と同様に図 9 中のル ープアンテナに流れる電流分布を抽出している。尚、ノイ ズ電流ベクトルは最高次ウェーブレットレベルの電流ベク トル分布とした。図 12 は抽出されたノイズ電流ベクトル分 布である。明らかに、何れの周波数に执いてもランダムな 方向を持つ電流ベタトル分布である。

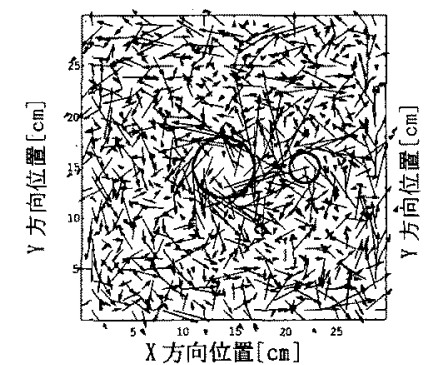

(a) $20 \mathrm{MHz}$

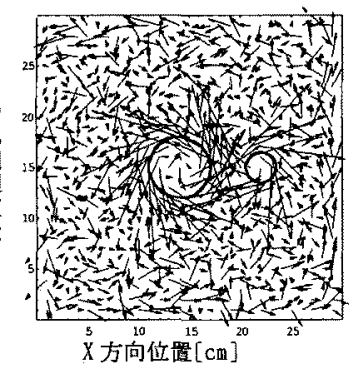

(b) $40 \mathrm{MHz}$

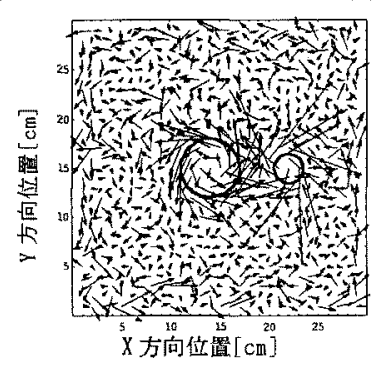

(c) $80 \mathrm{MHz}$.

図 9. 推定されたループアンテナの電流分布 Fig.9 Estimated current vector distribution. ${ }^{5,7.8}$ 


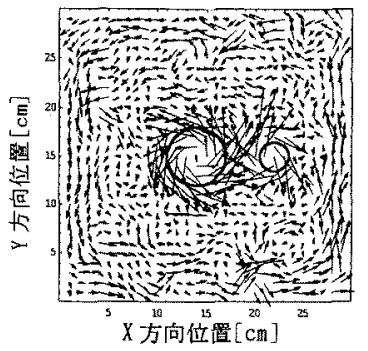

(a) $20 \mathrm{MHz}$

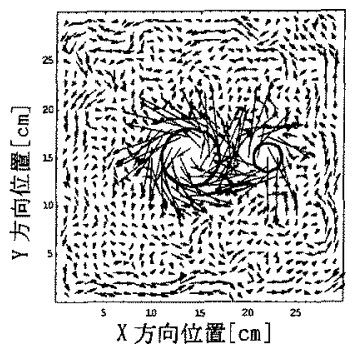

(b) $40 \mathrm{MHz}$

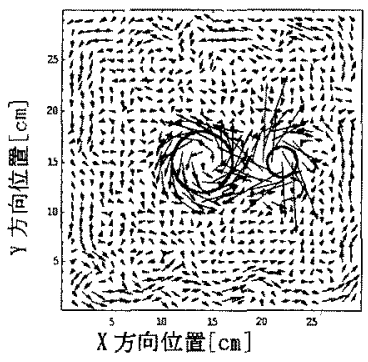

(c) $80 \mathrm{MHz}$.
図 10.データ圧縮法によるノイズ低減結果

Fig. 10 The noise reduction of current vector by the data compressed method.

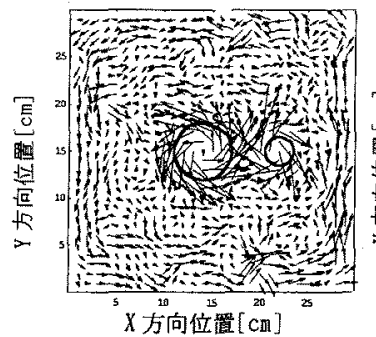

(a) $20 \mathrm{MHz}$

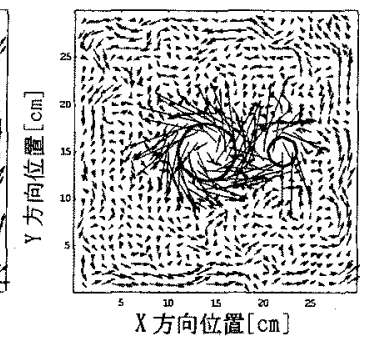

(b) $40 \mathrm{MHz}$

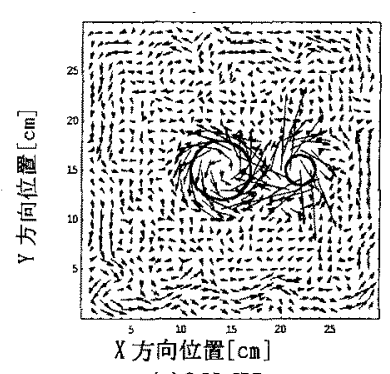

(c) $80 \mathrm{MHz}$
図 11. 多重解像度解析法によるノイズ低減結果 Fig.11 The noise reduction of current vector by the multi dimensional analysis method.

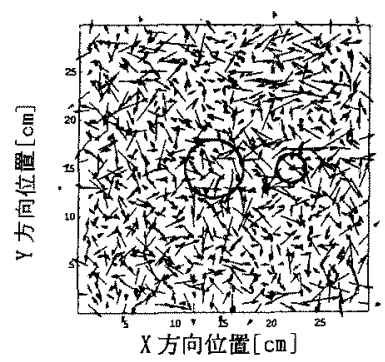

(a) $20 \mathrm{MHz}$

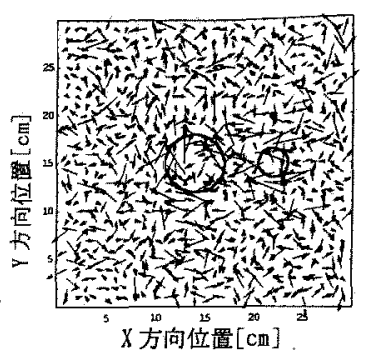

(b) $40 \mathrm{MHz}$

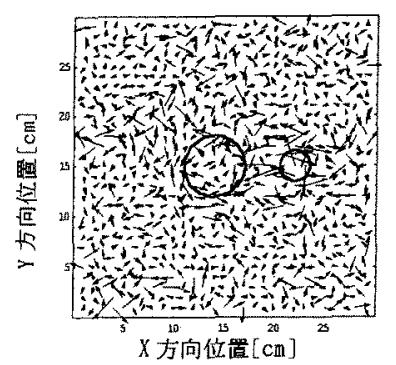

(c) $80 \mathrm{MHz}$.

図 12. 多重解像度解析法により抽出されたノイズ 電流ベクトル分布

Fig. 12 The extracted noise current vector by the multi dimensional analysis method.

\section{〈2.4〉 ワークステーション基板上の電流分布}

2.4.1 実験による電流ベクトル分布 図 13 に測定対象上 した、CPU の内部クロックは 80MHz、外部クロックは 40MHz、 周辺機器 $20 \mathrm{MHz}$ で動作しているNEC 社製のワークステーション の基板走示す。図 13(a)は(b)側からの見通し図である。この 基板上の電流ベクトル分布を基板裹面の磁界分布測定からル 一プアンテナの場合と同様に逆問題解析法により求めた結果 恤 14 に示与 7,8 磁界分布測定は、80MHz、40MHz、20MHz の各周波数についてそれぞれ行った。

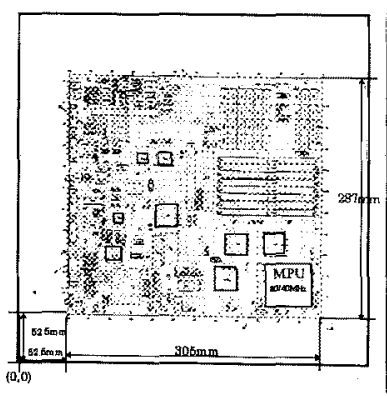

(a) Front side

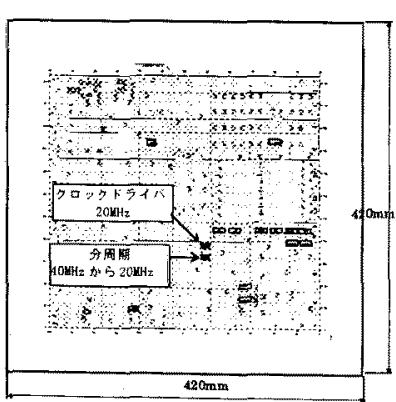

(b) Back side

図 13. 測定対象のプリント基板

Fig.13 Tested printed circuit board.

2.4.2 電流ベクトル分布ノイズ処理 図 15 にデータ压縮法 によって図 14 の電流ベクトル分布からノイズベクトルを低減 した結果を示す。ウェーブレット変換を行うためにデータ数を 2 のベき乗とする必要がある ${ }^{3}$ このため1ベクトル成分当た りの $27 \times 27$ 個のデータに0 要素を追加し、1 ベクトル成分当 たり $32 \times 32$ 個のデータとした ${ }^{9}$ 。1 成分当たり $32 \times 32$ 個のス ペクトラムを $16 \times 16$ 個八圧縮した。また、採用した基底関数 はサンプルデータと同様にドビッシーの8 次である。

図 15 の結果は、明らかに図 14 中の主要電流分布を抽出 
している。

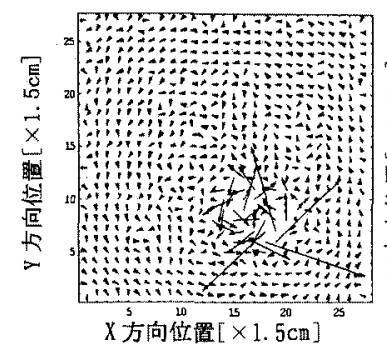

(a) $80 \mathrm{MHz}$

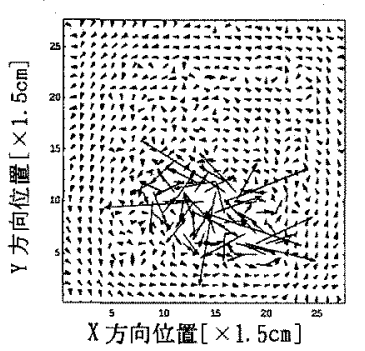

(b) $40 \mathrm{MHz}$

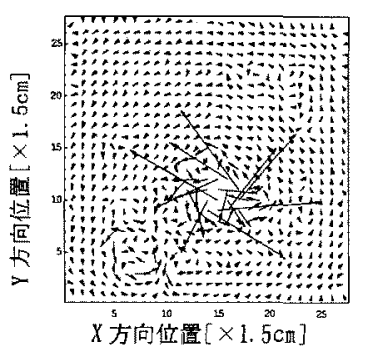

(c) $20 \mathrm{MHz}$

図 14. 磁界分布測定から計算された電流ベクトル分布

Fig. 14 Estimated current vector distribution. ${ }^{5,7,8}$

(a) $80 \mathrm{MHz}$, (b) $40 \mathrm{MHz}$ and (c) $20 \mathrm{MHz}$.

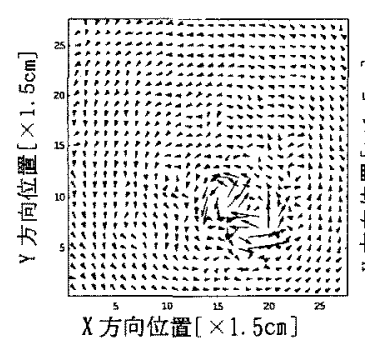

(a) $80 \mathrm{MHz}$

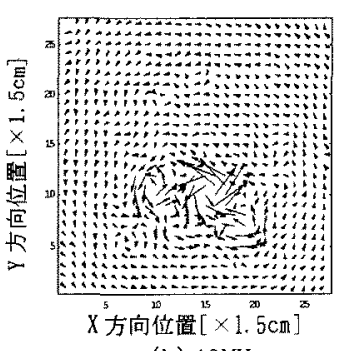

(b) $40 \mathrm{MHz}$

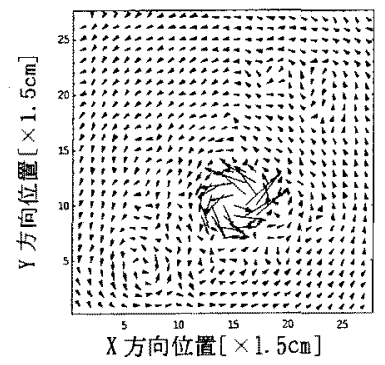

(c) $20 \mathrm{MHz}$
図 15.データ圧縮法によるノイズ低減結果

Fig. 15 The noise reduction of current vector by the data compressed method. (a) $80 \mathrm{MHz}$, (b) $40 \mathrm{MHz}$ and (c) $20 \mathrm{MHz}$.

次に多重解像度解析を行いノイズを低減した結果を図 16 に示す。図 16 の結果は、図 15 の結果と同様に図 14 中の主 要電流分布を抽出している。尚、ノイズ電流ベクトルは最 高次ウェーブレットレベルの電流ベクトル分布とした。図 17 は抽出されたノイズ電流べクトル分布である。明らかに、 何れの周波数にお゙いてもランダムな方向を持つ電流ベクト ル分布である。図 15,16 から何れの周波数の電流も CPU およ
びクロックドライバ付近を中心とした環状経路を流れること がわかる。80MHz においてはCPU 周辺、40MHz はCPU 周辺から 分周期などの周辺、20MHz はクロックドライバ周辺の環状電流 となっている。この結果は、基板の動作周波数に対応している。

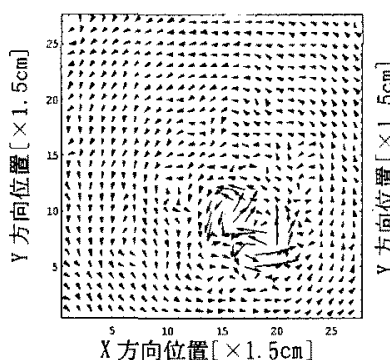

(a) $80 \mathrm{MHz}$

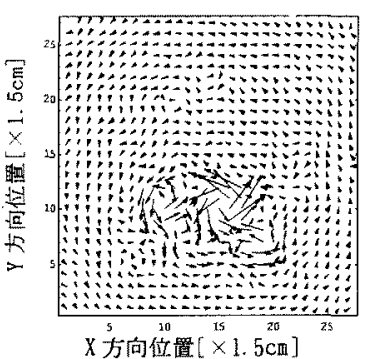

(b) $40 \mathrm{MHz}$

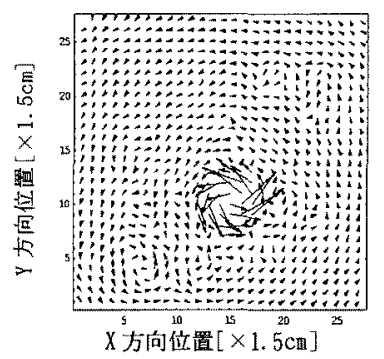

(c) $20 \mathrm{MHz}$

図 16.多重解像度解析法によるノイズ低減結果

Fig.16 The noise reduction of current vector by the multi dimensional analysis method. (a) $80 \mathrm{MHz}$, (b) $40 \mathrm{MHz}$ and (c) $20 \mathrm{MHz}$.

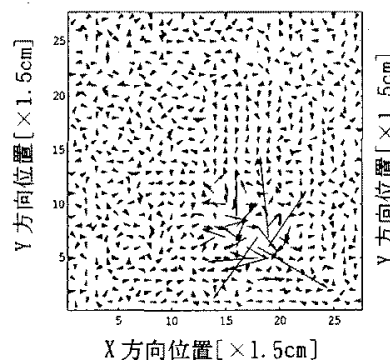

(a) $80 \mathrm{MHz}$

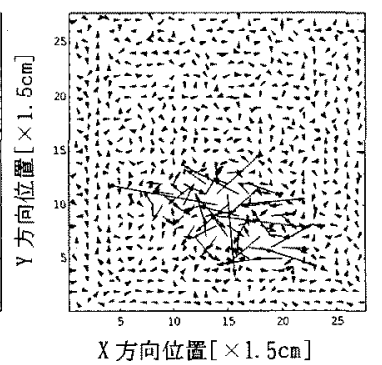

(b) $40 \mathrm{MHz}$

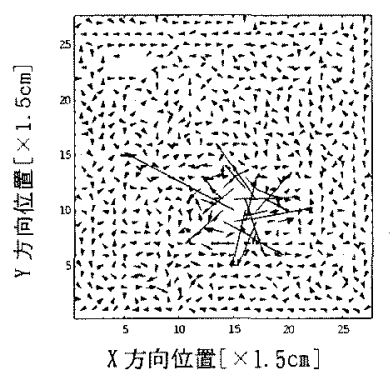

(c) $20 \mathrm{MHz}$

図 17. 多重解像度解析法により抽出されたノイズ 電流ベタトル分布

Fig. 17 The extracted noise current vector by the multi dimensional analysis method. (a) $80 \mathrm{MHz}$, (b) $40 \mathrm{MHz}$ and (c) $20 \mathrm{MHz}$. 
3.まとめ

本論文では、離散值系ウェーブレット変換をベクトルデ ータに適用し、ベクトルデータに含まれるノイズを低減す る方法を提案した。さらに、これを実際のプリント基板上 の主要電流ベクトル分布抽出へ適用した。

その結果、プリント基板上のノイズベクトル成分を分離 した主要な電流ベクトル分布が抽出でき、プリント基板か ら生ずる放射電磁界の発生源推定など逆問題解析の一端を担 う技術として有効であることが分かった。

(平成 9 年 9 月 8 日受付, 平成 10 年 3 月 2 日再受付)

文献

（1）山口昌哉、山田道夫、”ウェーブレット解析”、科学、 Vo1. 60、No. 6、June、pp. 398-405 (1990).

（2）山田道夫、”ウェーブレット解析とその応用”、電子 情報通信学会誌、Vol. 76、No. 5、pp. 518-528 (1993).

(3) 斎藤兆古、“Mathematicaによるウェーブレット変換” 朝倉書店（1996）.

（4）原田、早野、斎藤、“誘導加熱コイルの最適設計に関 する基礎的検討”、電気学会マグネティックス研究会 資料、MAG-96-187（1996）。

（5）斎藤兆古、“不適切な線形システムの Wavelet 変換解 析”電気学会マグネティックス研究会資料、MAG-9749、PP. 27-31 (1997)

（6）緑川、早野、斎藤、“離散值系ウェーブレット変換に よるノイズフィルタ評価の検討”、電気学会論文誌 A、 Vol. 117-A、No. 2、pp. 128-133 (1997).

（７）増田、緑川、斎藤、遠矢、“電子回路基板中の電流分 布推定に関寸る研究”、電気学会マグネティックス研 究会資料、MAG-97-128 (1997).

（８）篠原、早野、斎藤、“直接逆行列法を用いた渦電流分 布推定”、平成 9 年度電気学会全国大会予稿、Vol. 2, pp. 348-349 (1997).

(9) K.Yoda and Y.Saito, "A Wavelet Transform Approach to Inverse Problems of Vandermonde Type Systems" IEEE Trans.Magn, Vol.33,No.2, pp19551957 (1997).

（１００）土井達也、斎藤兆古、遠矢弘和、“ループ電流モデ ルによる磁界系逆問題解析”、電気学会マグネティッ クス研究会資料、MAG-96-151 (1996).

（1 1 $)$ 斎藤兆古、“電磁界系逆問題解析技術の進歩”、電気 学会論文誌A解説、 114 巻 6 号、pp. 432-438 (1994).
緑川 洋一 (学生員) 1970年 7月 4日生。1995年 3月 法政大学大学院工学研究科電気工学専攻修 士課程修了。現在、同大学大学院工学研究 科電気工学専攻博士後期課程在学中。主と して、高周波空心変圧器、ノイズフィルター に関する研究に従事。日本AEM学会会員。

増田 則夫 （正員）1961年 7月4日生。1984年 3月東京

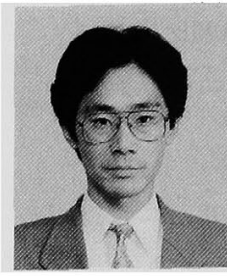
工業大学工学部機械工学科卒業。1986年3月 東京工業大学大学院総合理工工学研究科修 士課程修了。同年、日本電気株式会社に入 社、現在日本電気株式会社資源環境技術研 究所主任。主な研究分野は電子機器のEMC解 析及び電磁界計測に関する研究開発。電子 情報通信学会、回路実装学会会員。

阔藤 兆古（正員）1946年 7月24日生。1975年 3月法

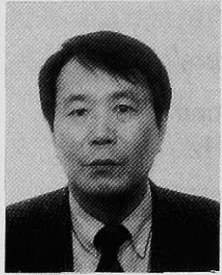
政大学大学院工学研究科博士課程修了。同 年同大学助手、1976年同講師、1978年同助 教授、1987年同教授、現在に至る。電磁気 学、電気機器、および大学院電磁力学の講 座を担当。主として、計算電磁力学、およ び高周波変圧器に関する研究に従事。工学 博士。International Journal of Applied Electromagnet ics in Materials, Editorial Board。 IEEE、電子情報通 信学会、日本忘用磁気学会、日本生体磁気学会、日本AEM 学会会員。

遠矢 弘和 （正員）1945年 6月 4日生。1968年 3月鹿児 島大学工学部電気工学科卒業。同年、日本 電気株式会社に入社、1992年12月より資源 環境技術研究所EMCセンター長。以後、EMC 技術の研究開発に従事。電子情報通信学会 会員。 